\title{
What do men want? The growing importance of men's characteristics for fertility
}

\section{Jan Van Bavel*}

In the generations who came of age in Europe around the turn of the 20th to the 21 st century, women were, for the first time in history, more educated than men. According to UNESCO statistics, until the 1970s, women made up less than $50 \%$ of all students enrolled in university-level education in virtually all European countries. But by 2000, the only European country where women were still a minority in tertiary education was Switzerland. ${ }^{1}$

Based on the extrapolation of the associations between women's educational attainment and fertility observed in the past, we might expect to see further declines in fertility in the future. But as I have argued previously, the implications of the reversal of the gender gap in education for family life cannot be grasped by extrapolating what we know from the vast literature on women's education and fertility (Van Bavel 2012). The further expansion of advanced education among women does not necessarily mean that we get "more of the same": e.g., more postponement and more childlessness.

Rather, I suspect that this reversal implies that we have crossed a tipping point with non-linear implications, and that a new demographic landscape is opening up. To make sense of this new landscape, we need to incorporate insights about processes of union formation and assortative mating into our fertility theories. This also means that the next generation of fertility research needs to pay more attention to male characteristics.

In this contribution to the debate, I argue that the fertility of the coming generations of highly educated women will depend to a large extent on the characteristics of the men with whom these women form (or fail to form) partnerships. In this argument, which focuses on heterosexual couples, I will use some initial results from my own ERC-sponsored GENDERBALL research project, which set out to investigate these issues (see http://genderball.wordpress.com/).

\footnotetext{
* Jan Van Bavel, KU Leuven - Centre for Sociological Research, Parkstraat 45 bus 3601, BE-3000 Leuven, Belgium

Email: Jan.VanBavel@kuleuven.be

1 http://www.uis.unesco.org/Education/
} 
Over the last three decades, two theoretical frameworks have dominated research on fertility: Beckerian new home economics and the second demographic transition. Both frameworks need major revisions if they are to be useful for making sense of the new demographic landscape.

\section{From specialisation to pooling, combining, and bargaining}

The Beckerian framework has been used in many studies to interpret how economic mechanisms affect fertility through income and price effects (Becker 1991). From earlier sociological models of the modern family (propagated by scholars like Talcott Parsons), Gary Becker copied a view of strongly specialised gender roles, with men specialising in gainful employment and women focusing on household chores and child care. For union formation, this view implies that a man's earning potential is an important factor in a woman's mate selection process, while a woman's earning potential is not as important to a man. In other words, it is assumed that women are looking for steady breadwinners, while men are looking for good homemakers.

This female homemaker-male breadwinner family model is clearly outdated. Even in its mid-20th-century heyday in Western Europe and North America, this model was mainly an ideal for the middle classes, but it was hardly universally realised, especially in the working classes. After reaching historically low levels in the 1950s and the early 1960s, the labour force participation of married women and mothers started to rise again (Pott-Buter 1993). In communist Eastern Europe, the male breadwinner family was neither a norm (quite the opposite) nor a reality, and female labour force participation levels were high. In these countries, women entered the labour market not just for ideological reasons, but also out of economic necessity (Brzozowska 2015). Currently, dual earner families are the norm across Europe and North America. In addition, men in these countries now do much larger shares of the household work than men of earlier generations (Goldscheider, Bernhardt and Lappegård 2015; Altintas and Sullivan 2016); even though, in general, women still take care of most of the work at home and men still earn most of the family income (Klesment and Van Bavel 2017).

While the shift in gender roles is thus "uneven" (England 2010) or "incomplete" (Esping-Andersen 2009), couples have effectively moved a long way in the direction of achieving a family model that involves pooling, bargaining, and combining, rather than strict specialisation along gender lines. In the new family model, the incomes of both partners are important for securing a respectable, middle-class standard of living. As a result, the woman's as well as the man's earning potential has become an important factor in mate selection. Today, women pursue higher education not just to improve their chances of meeting a well-educated partner, but to earn a degree that will pay off in the labour market. The returns to education have thus increased much more for women than for men, which may explain why college enrolment 
rates for women now surpass those of men (Goldin 2006; DiPrete and Buchmann 2006).

As having a high earning potential has become an attractive feature on the mating market for women as well as for men, unexpected demographic changes are being observed. Before the start of the GENDERBALL research project, I formulated hypotheses about the implications of the reversal of the gender gap in education for patterns of union formation (Van Bavel 2012). The hypotheses were based on conventional family demographic thinking, and were still heavily coloured by the Beckerian family model; i.e., they were based on the assumption that the typical woman, but not the typical man, was looking for a partner with a high earning potential; whereas a typical man was looking for a good homemaker. This assumption implies that there is a persistent tendency among men and women towards female hypergamy; i.e., a man is likely to select a female partner who is at most as highly educated as he is, and a woman is likely to select a male partner who is at least as highly educated as she is. The observation that more women than men have advanced education inspired the prediction that highly educated women would be more likely to remain single (as there are "too many" of them), and that highly educated men would be less likely to remain single (as they are in high demand).

The initial results of our project show that these predictions are wrong: rather than being more likely to remain single, women with a tertiary level degree are often partnered with a man who has a lower level degree (Grow and Van Bavel 2015; De Hauw, Grow and Van Bavel 2017). Assortative mating among highly educated people remains very strong, but the tendency of highly educated men to choose a partner of a similar attainment level has not increased with the gender gap reversal. If anything, it is the highly educated men rather than their highly educated female peers who have become more likely to remain single. At the lower end of the educational spectrum, the risk of remaining single has increased among women with low levels of education. Currently, less educated women are almost as likely to remain single as less educated men, who have very high rates of singlehood.

As a result of these developments, women are more likely than in the past to be the main breadwinner in the family. Women's relative contributions to the household budget are clearly associated with educational assortative mating: a woman who has more education than her husband is more likely to be the main earner in the family (Klesment and Van Bavel 2017). From a Beckerian perspective, this would imply that the opportunity costs of childbearing would be even greater for such a woman.

The Beckerian approach indeed implies that traditional hypergamic couples (in which the husband has more education than the wife) should have the highest fertility levels, while highly educated homogamous couples and hypogamic couples (in which the wife has more education than the husband) should have lower fertility levels. This turns out not to be the case. While highly educated homogamic couples have their first child at the most advanced ages, they eventually catch up to their peers, and have higher parity progression rates than hypergamic couples. The differences between hypogamic and hypergamic couples depend to a considerable degree on the context (Nitsche et al. 2018). 
Whether women with a high income or a high income potential have lower or higher fertility depends to a large extent on the elasticity of gender roles with respect to the shifted gender balance in education and in the labour market. If a woman meets a partner who is willing to help with the child care and the housework, or is willing to invest in the outsourcing of these jobs, her opportunity costs of childbearing will be relatively limited. But if a college-educated woman does not meet a man who is ready, willing, and able to take on these responsibilities, she will be less inclined to have children.

In sum, the results of these studies have two main implications. First, highly educated women are now partnering with a broader educational spectrum of men, including men who have less education and earn less than they do. Second, the characteristics of the male partner matter for the association between female education and fertility. Taken together, these findings imply that when studying the relationship between education and fertility, we should take into account men's as well as women's characteristics.

\section{Higher education, family formation, and union dissolution}

A second theoretical framework that has dominated fertility studies in recent decades is that of the second demographic transition (Lesthaeghe 1995; Van de Kaa 2003). In this framework, it is assumed that advanced education among women is associated with a number of lifestyle choices that result in lower fertility, and that these choices are motivated by individualised, post-materialist needs for selfdevelopment. For a woman, this means that she is no longer focused solely on her roles as wife and mother. Thus, it is anticipated that higher levels of education will be associated with lower marriage rates and higher divorce rates (as educated women are ready, willing, and able to leave unhappy marriages), and with higher rates of childlessness. On the other hand, given that educated women no longer feel the need to follow the life trajectories traditionally prescribed by their church or their parents, they may come to see unmarried cohabitation and childbearing outside of marriage as viable options.

These assumptions were perhaps applicable to the generations who came of age around the period when the theory was formulated, and in the geographic region where the authors of the theory were living and working at that time; i.e., in Western Europe. But this framework does not yield accurate predictions for the trends that are currently being observed across Europe. While highly educated women tend to marry at later ages than women with less education, they are not less likely to marry in general. The educational gradient in marriage depends on the country context: in countries with more traditional, specialised gender roles, better educated women are less likely to be married than less educated women; whereas in more gender egalitarian countries, better educated women are more rather than less likely to be married (Kalmijn 2013). Moreover, there is, in general, no positive educational gradient in divorce. Having a higher education has been found to be positively 
correlated with an elevated divorce risk in a limited number of countries only; i.e., in countries that are in the early stages of the spread of divorce, when the social and economic costs of divorce are particularly high. Over time, the educational gradient in divorce has become increasingly negative (Härkönen and Dronkers 2006). Finally, although there is evidence that in some countries the spread of extramarital childbearing may be driven by women's increased education (Vitali, Aassve and Lappegård 2015), having children outside of marriage is generally associated with low rather than high levels of education. In most of Europe, the least educated have higher first birth rates within cohabitation, and the most educated have higher first birth rates within marriage (Perelli-Harris et al. 2010).

Apart from their personal attitudes and circumstances, the crucial factor that determines the fertility of highly educated women is their partnering behaviour: i.e., whether a woman meets a steady partner who is fit to help her raise children. I therefore argue that when analysing fertility, it is crucial to look at the characteristics of the male partner. Regardless of whether they have more or less education, most women want to start a family. But we can assume that highly educated women do not just want to give birth; rather, they hope to raise "high quality" children. In other words, highly educated mothers want their children not just to survive, but to be well-nourished and well-educated, and to achieve a good standard of living and reasonably high levels of social status in their adult lives. To reach these goals, it is helpful to have a good partner. In the male breadwinner model, a woman might define a good partner as a man who earns a sufficiently large and steady income. In the new model, this criterion may still be important (perhaps more or less so depending on how much the woman earns herself), but the male partner will also be expected to perform household chores and provide child care. As I noted above, this willingness to help with childrearing tends to become even more important as a woman's contribution to the household income goes up (because the opportunity costs of having to do all the child care and housework by herself are higher). The greater the woman's contribution to the family budget, the more likely it is that a potential male partner's attitudes regarding family and childrearing responsibilities will among her main selection criteria.

Men's attitudes and skills with respect to family responsibilities are correlated with education, as education has cultural as well as economic dimensions. Thus, men's education may be expected to be a predictor of fertility. While earlier studies failed to find a consistent effect of men's education on fertility, Trimarchi and Van Bavel (2017) showed that this is because male education affects fertility primarily through the selection of men into certain unions. This is another reason why union formation and assortative mating should be integrated into fertility studies more than they have been in the past.

\section{Conclusion}

In sum, the reversal of the gender gap in education may imply that male characteristics are becoming more important for childbearing decisions. Unlike 
in the past, when men and women occupied separate spheres, with the husband being responsible for earning the family income and the wife being responsible for childrearing, women now want their male partners to have characteristics that may give men more leverage in decisions regarding fertility and childrearing. Hence, to find out where fertility is going, it may become more important to find out what men want. It is clear that highly educated women typically want male partners who do their share of the work in the family. But what do men want?

\section{References}

Altintas, E., and Sullivan, O. 2016. Fifty years of change updated: Cross-national gender convergence in housework. Demographic Research 35(August): 455-470.

Becker, G. S. 1991. A treatise on the family. Enlarged Edition. Cambridge, MA: Harvard University Press.

Brzozowska, Z. 2015. Female education and fertility under state socialism in central and eastern Europe. Population-E 70(4): 689-725.

De Hauw, Y., A. Grow, and J. Van Bavel 2017. The reversed gender gap in education and assortative mating in Europe. European Journal of Population 33(4): 445-474, DOI: $10.1007 / \mathrm{s} 10680-016-9407-\mathrm{z}$.

DiPrete, T. A., and Buchmann, C. 2006. Gender-specific trends in the value of education and the emerging gender gap in college completion. Demography 43(1): 1-24.

England, P. 2010. The gender revolution: Uneven and stalled. Gender E Society 24(2): $149-166$.

Esping-Andersen, G. 2009. The incomplete revolution. Adapting to women's new roles. Cambridge, UK: Polity Press.

Goldin, C. 2006. The quiet revolution that transformed women's employment, education, and family. American Economic Review 96(2): 1-21.

Goldscheider, F., Bernhardt, E., and Lappegård, T. 2015. The gender revolution? A framework for understanding changing family and demographic behavior. Population and Development Review 41(2): 207-239.

Grow, André and Jan Van Bavel 2015. Assortative mating and the reversal of gender inequality in education in Europe: An agent-based model. PLoS ONE 10(6): 1-24.

Härkönen, J. and Dronkers, J. 2006. Stability and change in the educational gradient of divorce. A comparison of seventeen countries. European Sociological Review 22(5): 501-517.

Kalmijn, M. 2013. The educational gradient in marriage: A comparison of 25 European countries. Demography 50(4): 1499-520.

Klesment, M. and J. Van Bavel 2017. The reversal of the gender gap in education, motherhood, and women as main earners in Europe. European Sociological Review 33(3): 465-481, DOI: $10.1093 /$ esr/jcw063.

Lesthaeghe, Ron. 1995. The second demographic transition in Western countries: an interpretation. In Gender and family change in industrialized countries, eds K. O. Mason and A.-M. Jensen, 17-62. Oxford: Clarendon Press. 
Nitsche, Natalie, Anna Matysiak, Jan Van Bavel, and Daniele Vignoli 2018. Partners' educational pairings and fertility across Europe. Demography (forthcoming).

Perelli-Harris, B., Sigle-Rushton, W., Kreyenfeld, M., Lappegård, T., Keizer, R., and Berghammer, C. 2010. The educational gradient of childbearing within cohabitation in Europe. Population and Development Review 36(4): 775-801.

Pott-Buter, H. A. 1993. Facts and fairy tales about female labor, family and fertility: A seven country comparison, 1850-1990. Amsterdam: Amsterdam University Press.

Trimarchi, Alessandra and Jan Van Bavel. 2017. Education and the transition to fatherhood: the role of selection into union. Demography 54(1): 119-144, DOI: 10.1007/s13524-0160533-3.

Van Bavel, Jan 2012. The reversal of gender inequality in education, union formation, and fertility in Europe. Vienna Yearbook of Population Research 10: 127-154.

Van de Kaa, Dirk J. 2003. Second demographic transition. In Encyclopedia of population, eds Paul Demeny and Geoffrey McNicoll, 872-875. New York: Macmillan.

Vitali, A., Aassve, A., and Lappegård, T. 2015. Diffusion of childbearing within cohabitation. Demography 52(2): 355-377. 
